Chapman University

Chapman University Digital Commons

\title{
Preparing First-Time Leaders for an Urban Public School District: An Action Research Study of a Collaborative District-University Partnership
}

\author{
Juanita Cleaver Simmons \\ University of Missouri - Columbia \\ Margaret Grogan \\ Chapman University, margaret.grogan@cgu.edu \\ Stacy Preis \\ University of Missouri - Columbia \\ Kristin Matthews \\ University of Missouri - Columbia \\ Sheila Smith-Anderson \\ University of Missouri - Columbia
}

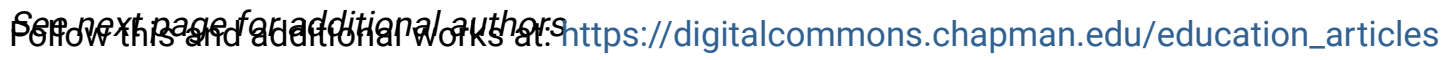 \\ Part of the Educational Administration and Supervision Commons, and the Educational Assessment, Evaluation, and Research Commons}

\section{Recommended Citation}

Simmons, J., Grogan, M., Preis, S., Matthews, K., Smith-Anderson, S., Walls, B. P., \& Jackson, A. (2007). Preparing first-time leaders for an urban public school district: An action research study of a collaborative district/university partnership. Journal of School Leadership, 17(5), 540-569.

This Article is brought to you for free and open access by the Attallah College of Educational Studies at Chapman University Digital Commons. It has been accepted for inclusion in Education Faculty Articles and Research by an authorized administrator of Chapman University Digital Commons. For more information, please contact laughtin@chapman.edu. 


\section{Preparing First-Time Leaders for an Urban Public School District: An Action Research Study of a Collaborative District-University Partnership}

\section{Comments}

This article was originally published in Journal of School Leadership, volume 17, issue 5, in 2007.

\section{Copyright}

Rowman \& Littlefield. Reproduced by permission of Rowman \& Littlefield. All rights reserved. Please contact the publisher for permission to copy, distribute or reprint.

\section{Authors}

Juanita Cleaver Simmons, Margaret Grogan, Stacy Preis, Kristin Matthews, Sheila Smith-Anderson, Betty Porter Walls, and Audrey Jackson 


\title{
Preparing First-Time Leaders
} for an Urban Public School District: An Action Research Study of a Collaborative District-University Partnership

\begin{abstract}
This article reports the results for the first cycle of an action research study about a district-university partnership. Two district facilitators and two university facilitators co-constructed a principal preparation program for an innercity school district to help prepare the next generation of building leaders. Twenty-two students participated in the 15-month nontraditional program. The study found that in preparing first-time school leaders, the most helpful experiences were those that developed self-understanding and readiness for the role change. New instructional techniques and the full-time residency facilitated this learning. It also found that the partnership, though providing new and exciting opportunities to deviate from the traditional preparation model, needed further development.
\end{abstract}

In the United States, formal degree programs in school leadership have been offered since the start of the 20th century. Although the programs have not all been the same, many included professors and adjunct professors' delivering research-based knowledge of educational administration,

Address correspondence to Juanita Cleaver Simmons, University of Missouri, Department of Educational Leadership and Policy Analysis, 202 Hill Hall, Columbia, MO 65211. E-mail: simmonsjm@missouri.edu. 
interspersed with anecdotes of practice. In addition, an internship in a school setting with a practicing principal or other administrator was an integral part of the process. That model has been severely criticized for outdated content and ineffective program delivery (Fry, O'Neill, \& Bottoms, 2006; Levine, 2005).

The criticisms stem from the fact that during the last century, professional expectations for school leaders have evolved with the changing political and social climate and the programs that prepare those leaders have been expected to evolve as well. However, there has been little change in the way that leaders have been prepared. Thus, since the 1980s, preparation programs in educational leadership have been under intense scrutiny, and there have been many calls for a redesign of the traditional program (see Levine, 2005).

Major recommendations from a University Continuing Education Association study (see Kochan, Jackson, \& Duke, 1999) coincided with an outcry from professional administrator organizations that demanded a closer association among higher education, the professional organizations, and districts to provide preparation outside conventional classroom settings (Ferrandino, 2001; Kochan, 1999; Tirozzi, 2001) and a complete overhaul of the content taught in leadership preparation (Fry, Bottoms, \& O'Neill, 2005; Hess \& Kelly, 2005). The major deficiency involved the lack of focus on improved student achievement and student learning in leadership preparation. There is a fundamental belief that leadership preparation must be reconceived to attend to this weakness.

This article reports on a study whose purpose was to investigate to what extent, if at all, a newly designed leadership preparation program attends to this call for improvement. Its research questions were as follows: First, to what extent, if at all, do the facilitators and mentor principals perceive that the interns have been prepared to make the transition from teacher to school leader in the Old City Public Schools? ${ }^{1}$ And to what extent, if at all, do the interns themselves perceive that they have been prepared? Second, to what extent, if at all, does the collaborative design of the Old City Leadership Program begin to address the concerns and criticisms found in the literature on principal preparation? First we discuss current recommendations from the literature for redesigning the content of leadership preparation programs. Then we consider the recommendations for improved program delivery.

'Old City is a pseudonym. Some of the district details have been changed to protect its identity. 


\section{CONTENT}

\section{A RECONCEPTION OF INSTRUCTIONAL LEADERSHIP FOCUSED ON STUDENT LEARNING}

If traditional preparation programs are to be redesigned to meet the challenges described here, research suggests starting with a common understanding of good classrooms and good schools (Smith \& Andrews, 1989). The goal is to graduate principals who can promote the development of good schools that produce high levels of learning for all children. Recent research has confirmed the pressing need for principals to be well-informed instructional leaders and resource providers whose main tasks include magnifying the capacity of educators and community members so that student learning is the highest priority (Cotton, 2003; Waters, Marzano, \& McNulty, 2003).

Students perform at high levels when schools are structured so that their educators design the kind of instruction that encourages students' active engagement in learning (Grogan \& Roland, 2003). In high-performing schools and districts, educators experience autonomy within a professional collegial community that allows teachers to team-or at least prepare collaboratively - to increase the learning of all students (Blase \& Blase, 1999; O'Donnell \& White, 2005).

The most important studies have aimed at identifying links between what principals do and at what levels students learn and perform academically. Interest in this work has been fueled by the persistent achievement gap that exists in schools across the country, which is especially pernicious in urban centers (Hill et al., 2000). Race and poverty are major factors associated with the achievement gap. The National Center for Children in Poverty (2006) reports that $17 \%$ of American children (12 million) under the age of 18 live in poverty. Poverty is especially prevalent among Black children (33\%) when compared to White children (10\%). Nearly $40 \%$ of American children (27 million) live in low-income families. The center also reports that children who are living in urban areas show an increasing pattern of low-income living. Approximately $51 \%$ of children who live in urban areas (8.9 million) live in low-income families-up from $48 \%$ in 2000 . The challenge for principals is to learn how to help teachers eliminate this gap.

\section{NO CHILD LEFT BEHIND}

Framed by the No Child Left Behind Act of 2001, the current high-stakes accountability context within which leaders must function today is a driving force behind leadership preparation redesign. According to the act, all 
students-including the subgroups of students with disabilities, Englishlanguage learners, students belonging to major racial groups, and economically disadvantaged students - must be proficient in reading, math, and science by 2014 (National Research Service, 2003).

However, research has documented that this force can impede good principal practices (see Duke, Butin, \& Sofka, 2003; Grogan \& Roland, 2003; Tucker, 2003). Studies in Virginia found that teachers felt compelled to cover material swiftly regardless of whether all students in the class understood it. Considerable pressure was applied to ensure that students were fully exposed to the breadth of content to be tested (Duke et al., 2003; Grogan \& Roland, 2003). Findings suggest that more than ever before, principals need to pay attention to the poor teaching that can be a by-product of the accountability reform. Student learning can be hampered by the way that the reform has been implemented in some buildings and districts.

Student learning does not depend on teachers' simply covering material. In an early study, Combleth (1990) found that in highly structured classrooms, learning opportunities were constrained. Although student leaming and student success on standardized and end-of-course tests are not necessarily the same thing, one does not have to preclude the other. Much depends on principals' attitudes toward teachers' autonomy and knowledge of good instruction. An externally imposed curriculum does not necessarily prevent teachers from providing opportunities for students to "take responsibility for their own learning, to be autonomous thinkers, to develop integrated understandings of concepts and to pose-and seek to answerimportant questions" (Brooks \& Brooks, 1993, p. 13). The key is to engage the students in their learning. However, the current pressure that principals are under today, to increase test scores at all costs, can militate against enlightened instructional leadership (Brown, 2006).

\section{REFORM}

Other recent approaches to leadership stress what the principals do and how they do it affect student achievement. With a meta-analysis of 30 years of studies on leadership and student achievement, Waters et al. (2003) created a balanced leadership framework listing 21 responsibilities that they demonstrated were connected to student achievement. One of their most significant findings was that an increase of one standard deviation in leadership ability (as measured by teachers' perceptions) could be correlated with an average student's achievement increase from the 50th to the 60th percentile. In a similar approach, Cotton (2003) conducted a meta-analysis of post-1985 research that looked at principal behaviors in relation to one 
or more student outcomes. The characteristics and behaviors that Cotton identified are also embedded in the Waters et al. framework.

What distinguishes this research from the previous is the understanding that in addition to desirable knowledge of instruction and related behaviors, a principal's grasp of effective organizational structures and policies, as well as mission and vision, can be associated with increased student achievement (Brewster \& Klump, 2005; McREL, 2005). In addition, effective leaders emphasize the importance of encouraging teachers' collaboration in building school community (Brewster \& Klump, 2005; Gonder, 1999; Wenger, 1999). Finally, leaders have an obligation to provide a physically, socially, and emotionally safe environment for their students (Cotton, 2003; Leithwood et al., 2004). Cicchinelli, Dean, Galvin, Goodwin, and Parsley (2006) emphasize that "school leadership teams must understand the big picture, be aware of the complexity of their schools' systems, and have a long-term plan for addressing those complexities" (p. 24). Change and reform within districts and buildings compose a major theme in this literature.

\section{DELIVERY}

Redesign of preparation programs includes not only more relevant and timely content and curriculum but also attention to the delivery of courses and experiences. Delivery of leadership preparation programs is influenced by numerous factors. Some states adhere to the Interstate School Leaders Licensure Consortium Standards, which influence program design, whereas other states may allow major universities to be the guiding force for development (Behar-Horenstein, 1995). Bredeson (2004) argues for the design of leadership programs that have a clear purpose and intentional structure. Otherwise, the result would be a "fragmented, often times incoherent collections of classes and faddish activities masquerading as professional learning" (p. 713). State licensure requirements underlie the basic components of a program, although they have more influence on curriculum than on structure (Grogan \& Roberson, 2002; Harle, 2000). Three design and delivery issues emerge from the literature as being most relevant to the program under discussion: cohorts, university-district collaboration, and internships.

\section{THE COHORT MODEL}

Most research on program delivery recommends a cohort model. The most commonly studied is a closed cohort, where students travel 
through the courses and experiences together. Many strengths of such a model have been identified, but certain characteristics are more important than others. There are distinct advantages to keeping students together as they experience the different components of a preparation program.

If instructors plan learning experiences that draw on adult learning theories appropriate for group settings, participants seem to benefit (B. G. Barnett \& Muse, 1993; Norris, Barnett, Basom, \& Yerkes, 1996). Learning that is authentic and relevant to participants' work and lives has been found to be effective, especially to prepare new school leaders (B. G. Barnett, Basom, Yerkes, \& Norris, 2000; Browne-Ferrigno, 2003; Tucker, Henig, \& Salmonowicz, 2005). In addition, continued networking with members of the cohort provides excellent support even after the program is completed (B. G. Barnett et al., 2000; B. G. Barnett \& Muse, 1993; Browne-Ferrigno \& Muth, 2003; McCabe, Ricciardi, \& Jamison, 2000; Milstein, 1995).

There are some documented drawbacks to the cohort model, however. Some cohort participants have cited as disadvantages the rigidity of course scheduling and the lack of opportunity for individual exploration (B. G. Barnett et al., 2000; Diller, 2004). Donaldson and Scribner (2003) noted that when a program keeps every student on the same schedule, practical constraints (e.g., students' time, other commitments, personal issues) restrict the depth at which students are willing and able to explore the concepts covered in the curriculum. Also, when students were preoccupied with the final product of their group work, creativity and divergent ideas became suppressed by intercohort competition.

\section{UNIVERSITY-DISTRICT COLLABORATION}

University-district collaboration is relatively new and understudied (but see Whitaker \& Barnett, 1999; Whitaker, King, \& Vogel, 2004). Many researchers and critics have encouraged a collaborative partnership between all stakeholders involved in principal preparation. Young, Peterson, and Short (2002) argue that no single organization, group, or individual can successfully take the reins of principal preparation and make substantive changes in leadership programs. There must be an acknowledgment of interdependency and shared accountability (Cambron-McCabe \& Cunningham, 2002). Levine (2005) advocates that theory-based university programs and practice-based alternate-route programs work together to create balance. Fry et al. (2005) recommend that universities and school districts collaborate during principal preparation, through developing 
explicit school-based assignments to complete during the internship; creating a handbook that jointly defines expectations, processes, and schedules; and ensuring a deeply committed program faculty when supervising principal interns.

Partnerships between schools and universities have the potential to bridge the gap between theory and practice, a frequent criticism of educational leadership preparation offered by universities (B. G. Barnett, 2005). However, successful partnerships involve collaboration and cooperation at all levels of each participating organization, even every level will not be directly involved (e.g., that of university chancellors; Grogan \& Roberson 2002; Whitaker \& Barnett, 1999). Many successful university-school district partnerships have had advisory, development, and redesign committees where all parties were well represented and had input on the structure and expectations for the partnership (Goldring \& Sims, 2005). In addition, to be as effective as possible, all partners should share a commitment to the partnership and respect what the other partners have to contribute (Whitaker \& Barnett, 1999).

\section{INTERNSHIPS}

Internships and other intensive field experiences have been found to be an integral part of any good program, and researchers have strongly recommended their further development (D. Barnett, 2004; Pounder, Reitzug, \& Young, 2002; Whitaker et al., 2004). Traditional internships involved students' clocking a number of hours in a building; however, many now believe that the internship must be an intense yearlong salaried opportunity to ensure a pool of well-prepared beginning administrators (Chenowith, Carr, \& Ruhl, 2002; Grogan \& Andrews, 2002). Davis, Darling-Hammond, LaPointe, and Meyerson (2005) stress that most adults learn best when they apply newly acquired knowledge in authentic settings and follow it by engaging in critical self-reflection (Brandt, 1990). The opportunities must be sustained. A few hours per week do not offer students the same experience. Browne-Ferrigno (2003) indicates that the internship is a key element in the essential transformation that occurs when students transition to their new role as principal. Teachers who are moving into administrative positions must be given the opportunity to let go of their old mind-sets and experience the modifications of self-esteem during a carefully developed and monitored setting. Effective mentoring by an expert principal is key to the success of the internship (Browne-Ferrigno \& Muth, 2004; Daresh, 2004). 


\section{PROGRAM DESIGN}

From this literature, we derived a set of guiding assumptions to ground the development of a program. These included focusing program content on leadership for learning and improved student outcomes. The foundations of the program included research-based leadership knowledge, skills, and attitudes most associated with the goal of improved student learning. Using relevant district data, we emphasized the need for reform of current district practices that would challenge the status quo. Moreover, to best deliver program experiences that would facilitate the learning of these key concepts, we designed elements that made use of best preparation practice from the research. The concept of a district-university partnership framed these elements, and it included the notion that all classroom experiences be co-constructed and co-delivered-a much more timeconsuming and human resource-intensive approach than that of team teaching. In addition, the full-time residency for each participant was designed to allow the intem to practice and reflect on recommended leadership approaches introduced and developed in the classroom. The partnership frame expressly intended to weave theory with practice.

What follows is a description of the Old City Leadership Program, which was designed to address the concerns identified in the literature, in an effort to provide the first cohort of interns in this urban district with the best possible leadership preparation.

\section{THE OLD CITY LEADERSHIP PROGRAM}

In March 2005, the members of a university educational leadership faculty and the leadership professionals of Old City Public Schools embarked on an intense collaboration to create the preliminary design of an urban principal preparation program to begin July 2005 and end June 2006. The literature discussed informed the design of the program, which was coconstructed and co-delivered by a team of four facilitators and by instructors from both institutions.

\section{INTENSIVE SUMMER PROGRAM}

The program included 5 weeks of intensive preparation, beginning in July 2005 . It started with a 1-week residency component on the university campus, to be followed by 4 weeks in Old City, to provide students with an opportunity to develop as a learning community (Kochan, 1999). During 
the residency on campus, students were immersed in leadership and relationship-building activities.

\section{YEARLONG RESIDENCY}

Once the school year started, each student worked closely with a mentor principal in the district during a yearlong residency that provided opportunities for aspirants to apply new knowledge in an authentic setting (Chenowith et al., 2002; Davis et al., 2005; Grogan \& Andrews, 2002). Four days were devoted to on-the-job training, with the fifth day and one evening devoted to workshop sessions and class time. The university provided course credit for these learning experiences. The problems-oriented curriculum addressed district issues as well as national issues.

\section{PLANNING SUMMER}

During the second summer of the project, the students prepared for their transition to a leadership role, in a 3-week final course experience. They engaged in practical activities focused on specialized knowledge of district policies and procedures. During this time, the students interviewed for administrative positions with the district. As a result, 13 out of 22 students were placed in administrative positions for the 2006-2007 school year-1 principal, 1 central office administrator, and 11 assistant principals.

\section{MENTORING}

An integral component of this program involved the inclusion of mentor principals. Mentors were viewed as full partners in the development and delivery of the integrated learning experiences, as described. Mentors were experienced district principals with good reputations for leadership. Regarding assignment, a pair of students was placed with a mentor principal in his or her building. Most students remained with the principal throughout the year, although a few students were reassigned because of personality conflicts.

\section{RECRUITMENT AND SELECTION}

The university worked with the Old City leadership professionals to identify potential aspirants and mentors, with priority given to educators 
who were already working in the school district. District leaders also helped to identify potential candidates, and individuals were given an opportunity to self-identify.

The professors and the leadership professionals in the school system developed criteria to identify successful applicants. Such criteria included a record of high performance during the last 2-3 years, strong knowledge of appropriate instructional strategies, sound ethical principles (Starratt, 2004), a willingness to disrupt the status quo that has not served all students well in this system (Grogan, 1999; Waters et al., 2003), and the courage to serve as a transformational leader who understands the need for change (Scribner, Cockrell, Cockrell, \& Valentine, 1999). Most important was a commitment to urban education.

\section{STUDY DESIGN AND METHODS}

This was an action research project using qualitative data to investigate the experiences of students and facilitators in the program. Based on the New Leaders Academy Program, ${ }^{2}$ the Old City program was co-constructed by leadership professionals in the district with scholars and researchers from higher education. The goal was to graduate future administrators, with a master's degree and state certification, who had the skills and dispositions to promote the development of good schools and teachers that facilitate high levels of student learning.

Realizing that our efforts to prepare principals as instructional leaders would not be achieved by the end of a 1-year program, we concentrated this first cycle of study on determining whether the interns were developing the leader attitudes and behaviors as recommended in the literature. We knew that most interns would be placed as assistant principals, if they were placed at all. Action research was therefore deemed the best methodological approach for this study because of the importance given to practical knowing: "the knowledge that brings the other ... forms of knowing to full fruition by doing appropriate things, skillfully and competently" (Coghlan \& Brannick, 2005, p. 32; italics in the original). Our aim was to learn how to do leadership preparation so that all the children in public schools can be served better than they have been.

¿The New Leaders $\Lambda$ cademy Program recruits, prepares, and supports aspiring public school leaders. This leadership development program employs problem-based and action-learning methodologies to prepare participants to lead instructional improvement efforts in urban districts (sec also http://www.nycleadershipacademy.org/). 
The quality of action research depends on the extent to which it addresses a significant problem in the organization, becomes guided by a reflexive concern for practical outcomes, and includes a plurality of knowing (Bradbury \& Reason, 2001; Coghlan \& Brannick, 2005). For this district at this time, the necessity to replace rapidly retiring and exiting administrators was a matter of urgency. As such, the outcomes of this research were important to help strengthen principal preparation in the district. Also, in this climate of critiquing leadership preparation, the question of how to improve programs looms large for the university. Thus, our undertaking this research is pertinent for both partners in this collaboration. As researchers engaged in this inquiry, we bring different kinds of expertise and conceptual strengths. Our collaboration ensures that the knowledge that we generate emerge from our different standpoints.

During the course of the program, the action research approach (Coghlan \& Brannick, 2005; Herr \& Anderson, 2005) meant that facilitators and participants reflectively deliberated on what worked and what needed improvement with reference to the program's ultimate goal of nurturing a new generation of urban leaders. One cycle of the action research was conducted during the 2005-2006 academic year, including four phasesnamely, diagnosing, planning action, taking action, and evaluating action (Coghlan \& Brannick, 2005).

\section{CYCLE 1}

The diagnosing phase occurred during April-May 2005 and included the literature reviews by the university instructors in preparation for the program. This work coincided with the planning-action phase, which occurred with the Old City leadership professionals April-June 2005. The taking-action phase then occurred from July 2005 to June 2006, during which time the program was delivered. The evaluating-action phase began as early as January 2006 , when the data from the first set of interviews were analyzed. This phase has continued through the beginning of the first phase of the new cycle with the second cohort and will likely continue throughout the second year of the program as the new administrators share with us their experiences on the job. Phases in action research cycles continue to spiral alongside new phases in new cycles, each one strengthening the next. Thus, research conducted with the first cohort provides data not only for the evaluating-action phase of the first cycle but for the diagnosing, planning-action, and taking-action phases for the second cycle of the project, begun in July 2006 with the second cohort of the Old City Leadership Program. 


\section{RESEARCHERS AND PARTICIPANTS}

The action research team included the team of four facilitators-two African American university professors and two African American leadership professionals from the district (all women)-one White university professor, who was a guest instructor in the program, and two White graduate research assistants, who conducted all of the interviews (all women as well). The objectives of the research included not only refining the Old City Leadership Program in progress but also renewing the department's other leadership preparation initiatives. Lessons learned from this innovative program will be incorporated into other university leadership preparation programs.

\section{SOURCES OF DATA}

There were three sets of interview data. First, a graduate research assistant not involved with instruction conducted 60 - to 90-minute face-toface interviews with all interns in November 2005. Interns were asked whether the program thus far had helped them to develop their leadership skills and, if so, in what ways. Interns were also asked for general strengths and weaknesses of the program and for suggestions of what to change so that they would be able to develop their potential as fully as possible (see appendix for sample questions). A second set of interviews was then conducted in April 2006 by the same graduate research assistant, in focus groups of four or five interns. These interviews were designed to explore how the interns were experiencing the full-time internship in which they had been involved all year and to gauge their development as leaders. Finally, at the end of the program, in July 2006, a second graduate research assistant who had not been involved with any aspect of the program interviewed the 12 mentor principals face-to-face for $60-90$ minutes.

Instructional sessions were videotaped. Data from reflective journals were also drawn on, as were e-mail and facilitator observations. Interns and instructors constructed their meanings through readings, experiences, dialogue, and reflections and shared those meanings with all. Not only were the data used to fine-tune the ongoing instructional delivery program, but they were instrumental in continuing to shape the ongoing design of the residency experiences for participants.

All the interviews were taped and transcribed, and all researchers read and coded the transcripts. Several meetings were held to develop themes and determine the most dominant. As described earlier, the following research findings compose the feedback and evaluation phase of the first action research cycle. 


\section{PARTICIPANTS AND SETTING}

The first cohort consisted of 23 participants, who were screened and selected by a joint committee of university and district professionals. Of the 23 students, 22 completed the intensive 12 -month program and yearlong internship. One White woman withdrew from the program for health reasons. Of the 22 remaining, 14 were African American, 7 were White, and 1 was Latina. There were 3 males (2 African American and 1 White) and 19 females ( 6 White, 12 African American, and 1 Latina).

Participants were 24 to 61 years old. All participants had 2 or more years of teaching experience, and each had taught in the Old City schools for a minimum of 2 years. Their years of teaching experience ranged from 2 to 36 , with an average of 10 years in the teaching profession. Before entering the program, 2 participants had a background in early childhood education, 11 had elementary school experience, 2 had worked in middle schools, and 3 were high school teachers. Four were special education teachers across levels, and 1 was a speech pathologist. One had also been a police officer, 1 an attorney, and several had worked in business settings before becoming educators.

Old City is one of the largest school districts in this Midwestern state, with more than 35,000 students. This multiethnic district includes $81.6 \%$ African American students; $14.8 \%$ White; and 3.6\% Asian, Hispanic, and Indian. Nearly $93 \%$ of students qualify for free or reduced-price lunch. The district's dropout rate of $15.7 \%$ is more than 4 times the statewide rate. The graduation rate is $58.6 \%$, compared to the statewide rate of $85.7 \%$. Fewer than 1 student out of 4 enters a 4 -year college or university after graduation. The average ACT for the district is 17.3, compared to the state average of 21.6. Since 2002, the district has been plagued with superintendent turnover; it has faced a significant financial shortfall, requiring school closings and staff layoffs; and it continues to be only provisionally accredited by the state. These challenges have directly affected the district's climate for learning and leadership development.

\section{FINDINGS}

Using the framework of a university-district partnership, two major themes emerged in this study. The first-namely, transitioning from teacher to school leader-reflects the professional development of the interns over the course of the year. The emphasis on this development was important to the district, with its increasing administrator retirements and 
resignations. The second-program innovation-deals with the partners' differing perspectives of how the participants experienced innovative aspects of the program, at least for the Old City School District. Although both partners valued changing the way that leaders were prepared, mindful of Levine's criticisms (2005), the university was heavily invested in learning how the new approaches might work.

\section{TRANSITIONING FROM TEACHER TO SCHOOL LEADER}

The first theme-transitioning from teacher to school leader-includes three related aspects: changing roles, sense of self, and readiness. This theme captures the intense feelings expressed by the interns as they moved out of their comfort zones as teachers. Although placed as administrative interns in full-time internships, they were all still part of the same district in which they had been teachers. Therefore, the transition was not immediate but spread across the course of the year. For some, changing roles involved simply changing perspectives, but for others, a stronger sense of self was needed, and for those who made the transition, at least emotionally, a sense of readiness was crucial.

Changing roles. Understandably, many interns initially identified with the teacher role:

I did come into the program as a teacher, so I'm kind of defensive for the teachers, but now I'm starting to see that sometimes it's not about you. You have to step back and just look at things on how it will benefit the whole. (Sally, Interview 1) ${ }^{3}$

And before the interns could even start to build their leadership skills, they had to acknowledge the difference between the environment they were leaving and the one they were entering:

As a classroom teacher, your focus is primarily your classroom, and you really don't look at the big picture. But as a principal, looking through that lens is almost like seeing a maze with several different avenues, and you have to make sure they all connect and that there is an outlet. (Maggie, Interview 2)

Early in the internship, the interns recognized the facets of administration that they had been unable to see as teachers. They were open about their lack of understanding and even their misconceptions of the principalship. However, despite the dramatic change in responsibilities and vantage points, the interns, overall, were positive about moving into administration. They admit-

${ }^{3}$ Interns are identified by first-name pseudonyms. Their comments were recorded during the first interview (Interview 1) and the focus group interview (Interview 2). 
ted feeling overwhelmed, but they met the challenge with the kind of attitude reflected in the following quote: "It's just absolutely hairy from the second you walk into the door until the second you drag your worn-out body from the building and crawl to your car. I like that" (Lisa, Interview 1).

Mentors took it as part of their role to make sure that the interns were seeing the big picture and making the connections between all who will be affected by what they do:

You must believe that your job is an important job and that children are going to be impacted by everything you say and do. You must value people-from the child who may be the most disruptive child to that child who is the greatest academic asset. You must also value staff members, and you must be able to project that the adult in your building is an extremely valuable part of this institution. (Isobel Yates, Interview 3$)^{4}$

Interns and mentors frequently mentioned how the full-time internship reinforced the role change:

One of the things that I found most useful was actually experiencing all of the things a principal goes through in the course of a day. We've learned a lot about curriculum; we've learned about a lot of different things in class, but to couple those with a principal's day and the timelines that go with has been very interesting for me. It shows you that you hit the ground running and that you continue to run even when the day is over. (Maggie, Interview 2)

Sense of self. Mentors were aware of the interns' anxiety, and they worked with the interns to help them build strong-enough senses of self in which they would be comfortable in the transition to school leader; that is, the internship gave the intern "the opportunity to participate in many administrative functions.... so it was like riding a bicycle with training wheels" (Leonard Robbins, Interview 3).

As such, the mentors expected the interns to take risks and make errors:

I tell people everyday, "No one has all the knowledge. You make a mistake. You try to do the very best you can. Some days are great, and some days things aren't going to go right no matter what. You wake up each day to a fresh day, and you go on." (Jeanne Perry, Interview 3)

Mentors tried to be professional role models and to help the interns become reflective practitioners. One mentor said,

We would have conversations about how we could have done this differently. And I always use "we" because [the interns] were part of my team at that time. I would say, "How could we have done this differently?" You know you

${ }^{4}$ Mentor principals are identified by first- and last-name pseudonyms. All their comments were recorded during their only interview (Interview 3). 
could almost determine the outcome by how you handle the situation. (Harris Templeton, Interview 3 )

\section{Self-discovery accompanied this transition:}

I have definitely become more reflective, not just professionally but personally. This time last year, I did not spend as much time thinking about what I was doing and why I was doing it. It was kind of like I was a machine, just doing it. (Gabrielle, Interview 2)

Furthermore, interns learned to have courage to reshape their selves, based on new expectations of leadership:

So I'm learning how to pace myself, but I'm learning how to take care also because I think it is important. . . . I looked at the superintendent's team. Most of his team members are fit, slim, and energetic, and that represents something. So if I'm going to be a part of that team, I know I have to project a certain image. So that's why I'm doing certain things. I see my entire lifestyle changing, not just what I do at work changing. (Anne, Interview 1)

Readiness. There was strong agreement among mentor principals and facilitators that all the interns experienced significant personal and professional growth throughout the course of the program-a sentiment shared by the interns themselves as well. Many interns (but not all) felt ready to make the transition, and some mentors expressed likewise:

I felt [that] both of them were ready. They were ready to take on a principalship. That is how strongly I felt about the two people who were with me. They were very qualified individuals. (Daisy Green, Interview 3)

But the following mentor qualifies her enthusiasm with a concern over district alignment with the program:

I think it is an excellent program. I liked the fact that these interns are being trained in [the city schools]. I would like to see greater coordination between district's administration and the [leadership] program, ... greater assuring that the interns will be ready to take their places in [the city schools]. (Bella Johnson, Interview 3)

In addition, instructors' observations and mentor principals' comments revealed that whereas some interns were ready for the challenge, others were not, and others were probably not good candidates for leadership at all. Few mentors were candid on this point during the interviews, but one mentor put it this way:

I think what happened at the end of the whole process is that we had two individuals who wanted to be principals and we needed to determine their abilities to do that. One of my mentees is now an [administrator]. It was 
apparent that she had the necessary skills and demeanor and the attitude to work in [the] district. I still talk to her because no matter what you do in this process, you don't know everything. ... The other person won't speak to either one of us now. (Josh Miller, Interview 3)

Informed by the literature of what a good instructional leader knows and is able to do, we designed the delivery of the program to help interns make the transition from teacher to school leader. That not all were able to make that transition suggests that we need to refine our selection process, as well as provide individualized support to some interns. What we learned most about the program from this theme was that the program exposed the interns to the possibility of making a transition and it offered support for them as they took the necessary risks. We have understood that to transition from a teacher to a school leader, it is important to, first, recognize the misconceptions of what the principal does and needs to know and, second, gain good knowledge of the self. Finally, for some individuals, the threads come together in the form of readiness to change roles. Readiness depends not only on knowledge acquired but also on one's self-readiness and others' believing the time has come. In the next theme, we learn about how the structures and components of the program design combined to support and detract from the transition process.

\section{PROGRAM INNOVATION}

The second theme-program innovation-includes three related aspects: new instructional approaches, full-time mentoring, and district-university partnership. This theme deals with participants' perceptions of our co-constructed efforts to create a program that quite radically differed from past district and university programs. New instructional approaches emerged as being helpful to interns as they made the transition discussed earlier. Full-time mentoring from the building principals became a hallmark of the program, given that no other preparation program in the district had afforded teachers the luxury of being assigned full-time for a year to practice leadership duties. However, participants wondered about the value of the co-constructed design and delivery model. Creating a partnership to co-construct and co-deliver the program was fundamental to the effort, but as an innovation and apart from the structural elements, little had been thought through in this inaugural year.

New instructional approaches. Interns noticed the collaborative approach taken by the facilitators, stating that the instructors

really flow back and forth. When one is missing that word, that one jumps in and gives that word, and it teaches us and shows us how to work together as 
a cohort. That's the whole point of being part of this cohort. (Sarah, Interview 1 )

Getting away from the highly criticized direct instructional approaches, facilitators used new techniques designed to promote self-awareness and the development of leadership skills. The techniques that seemed to make the most impression on the interns were as follows: (a) 360-degree feedback, a process for giving honest feedback to a project team leader who is charged with the responsibility of organizing collaboration strategies for completing simulated school events (at the completion of the activity, team members use an evaluation rubric to assess the leader's effectiveness in demonstrating the designated leadership dimensions-e.g., personal behavior, resilience, communication, situational problem solving, and team/task/project management); (b) "I see, I hear," a low-inference technique for helping to remove judgment from fact-gathering exercises; and (c) ordered sharing, or individual reflections on provocative statements about leadership:

That 360-degree feedback is hard, but self-examination is hard, and that's the whole point of that process. I hated it; it created a lot of strife within our [group], but I think the strife would have been there before, but it would have been submerged. The 360 brought it out. (Kimberly, Interview 1)

Discussing different group techniques, an intern observed,

I love ordered sharing, and it's something I intend to do with my teachers when I become a principal. . . . I [also] like it when we do group projects because everybody ... has their own individual talents. As a principal, you have to learn to use that to your advantage. (Tom, Interview 1)

Interns had to collaborate with one another throughout the program, gathering current research on relevant issues and applying it to the district context. They were constantly presenting projects to their peers and district observers. However, mentor principals were not always in favor of such intense class work:

The best kind of learning is doing it; the best kind of professional development is doing it and then going back and talking about what you are doing and relating it to the literature you are reading. That I think is the great part of [this] program. If I may be candid . . . I do think that they had a little bit too much to do-the readings, the projects that they had to do, as well as the day-to-day work in the schools. . . . I often wondered if they really were able to understand what was going on in the schools because they were thinking about the paper that was due the next day. (Laura Albert, Interview 3) 
Full-time mentoring. As might be expected, the mentor principals had different philosophies on how to best prepare the interns for future leadership positions. One intern described the first time that he met his mentor:

He took 3 hours of his time, and he presented us ... an outline of items that he expected us to complete before the end of the program.... When he talks to [the other intern] and I and the Blackberry goes off, 9 times out of 10 , he doesn't even look at it. He says, "I'm with you." He lets it ring. (Ron, Interview 1)

But the following comment is a sharp contrast to the approach taken by the aforementioned mentor:

If we asked to do things, we were allowed to do them, but there was no real course of action for us, so we just had to decide that we need to learn this and so we are going to ask if we can. That was really the only way that we received as much information as we did from the mentor principal. (Maggie, Interview 2)

Full-time mentoring needs to be learned and practiced. Several interns experienced little structure in the buildings. For mentoring to be an innovative technique, preparing and developing mentors in line with program goals would be an important component for the next cohort. When it works, mentoring continues beyond the initial placement:

It's really a wonderful experience. I mean, he would be a person after the program [that] if I had questions about something, I would call him. I would consider him .... a lifelong mentor ... because I really value his opinion and admire his tenacity. (Hayley, Interview 1)

Partnership between the school district and the university. To develop this innovative mentoring process, we needed to extend the collaboration between district and university to include working with the mentors. Despite intentions to do so, we had only a few meetings with the mentors this first year. Thus, the mentor principals had the most to say about the partnership between the school district and the university, and their comments suggest some obvious benefits: "[The partnership] just had some really top-notch instructors from the university, and they are really prepared" (Elizabeth Hanson, Interview 3).

But more than one mentor expressed a desire to be directly involved in the planning and delivery of the program:

Right now I feel like the university is doing the course work and the mentors are doing the practical work, but there needs to be more bridges between [the university, the mentors, and the interns].... It gets confusing if you are 
a mentee and you are spending 12 hours doing class work. And then another 12 hours I'm asking [her] to do these things. You know, we could probably work together a little bit better to make it a better experience. (Josh Miller, Interview 3)

University involvement in the program was another aspect of the partnership that was not working as well as it could have. The interns lamented the absence of their academic advisors from the university, located at some distance from the district. On one hand, the interns were pleased that this university was involved in their leadership preparation, but on the other, they thought that the relationship left something to be desired:

The university has been a big force in this, and I feel we really haven't been able to take advantage of it. I know I've only met my advisor once for lunch, and he drove all the way down here to meet with us. ... I would love to be able to go to the university for the weekend or a Saturday to hear Professor or Professor in particular. (Angela, Interview 2)

A real challenge for the partnership was how to connect the research and leadership theory of the university instructors to the day-to-day operation of the district. The following comment illustrates the loosely coupled nature of the partnership:

The strength of this program is also the weakness of this program, and that is anticipating the type of scenarios that occur in urban education and, in particular, Old City Schools. For that reason, it is highly important that we continue to strengthen the link between the theory and the practice. The university has the theory; however, we must take the time and truly mesh the two together through the problem-based scenarios that will better prepare our aspirants. (Professor Thomas)

Program participants' experience of the innovations clearly depended on whether they were interns in the program, mentor principals, or facilitators. Understandably, facilitators' perspectives were colored by context-those immersed in the district on a daily basis interpreted events quite differently from those who were at a distance. However, a strong sense of trying something new pervaded most views. The novel approaches to instruction, the fulltime commitment of the internship, and the somewhat-unexamined nature of the partnership all contributed to a sense of breaking with the traditions of leadership preparation in both institutions:

Trailblazing was also one of the strengths of the overall program. As a facilitator, I felt motivated to try unique and innovative activities. Since there was no

The facilitators are identified by last-name pseudonyms and the title professor. 
set model carved, we had the freedom to plan new and interesting activities. The New York Leaders training had provided several bases for innovative activities and lots of contemporary research. It was as though Pandora's box was opened, with millions of possibilities for reforming districts. (Professor Lane)

\section{DISCUSSION}

The first research question was, to what extent, if at all, do the facilitators and mentor principals perceive that the interns have been prepared to make the transition from teacher to school leader in the Old City Public Schools? And to what extent, if at all, do the interns themselves perceive that they have been prepared? This question investigated the extent to which participants felt they had made, and were judged to have made, the transition from seeing themselves as teachers to seeing themselves as prepared administrators. The data tell us that the facilitators and mentor principals believed that most of the interns were ready-and that the interns themselves believed that they were ready-and that the intensive internship played a large part in this transformation of roles (Browne-Ferrigno, 2003). As stated earlier, not all in the cohort were judged to be ready, nor did they judge themselves to be ready; additionally, the instructors became aware, as the year progressed, that they did not have a process in place to move incompetent interns out of the program.

One of the major advantages of having the yearlong residency was that it provided facilitators and mentors with many occasions to observe how interns handled situations. Most interns gained experiences that opened their eyes to good practices (Chenowith et al, 2002), and their leadership responses in class sessions and in the buildings were noted. When possible, instructors used such teachable moments to reinforce and reteach points made in class. Mentors spent many hours with the interns debriefing their actions and reactions. Mentors did not take the practice of judging lightly- especially when deeming an intern incompetent-and in the end, only a few interns were considered poor administrator candidates. Some were judged as being unprepared and will likely be given other opportunities to interview for administrative positions as they develop further confidence.

Relevant to the notion of transition, interns reported feeling an increase in not only their technical and professional skills but also their selfdevelopment (Davis et al., 2005; Schon, 1983). They described many instructional techniques as being quite helpful to this growth-particularly, the 360 degree feedback. The interns also highly valued the practical, hands-on opportunities provided by district personnel and were proud when they could demonstrate appropriate knowledge in the buildings. As Cotton (2003) and 
Waters et al. (2003) advocate, part of the cohort experience involves interns' expressing the strength that they derived from community building. They discovered much about themselves as they participated in group activities, although some interns thought that they spent too long with one group. The facilitators believed that they provided good coaching of leadership skills and dispositions during the many group projects.

The second research question was, to what extent, if at all, does the collaborative design of the Old City Leadership Program address the concerns and criticisms found in the literature on principal preparation? This question explored the extent to which this program, in moving away from the traditionally weak university-centric approach, used innovative learning activities that helped ready the interns for first-time school leadership. In this first cycle of our research project, we cannot know how well, if at all, we are preparing instructional leaders. We have not been able to observe the graduates of the program on the job or see how well students in their buildings are learning (Knapp, Copland, Plecki, \& Portin, 2006). Indeed, given that only one intern has been assigned to a principalship, we are unlikely to get a full sense of the effects of our preparation until several former interns are in the role. These sources of evidence will be utilized in the second and subsequent cycles of this project.

However, in reflecting on this formal district-university partnership (Fry et al., 2006; Grogan \& Andrews, 2002; Young et al., 2002), the university facilitators and district leadership professionals believe that they have made a good-faith effort to engage in a leadership preparation program that is coconstructed and co-delivered. The interns remarked on many positive characteristics of the partnership, including collaborative teaching and differentiation of expertise, yet they noted some inconsistencies as well: Instructors did not always provide enough feedback on written assignments. University advisors were not always available, nor were they as present as the interns wished they were. The cultures and organizational structures of the two institutions proved to be difficult to navigate, as Goldring and Sims (2005) argue.

Instructional approaches that deviated from the didactic lectures of the traditional programs were viewed positively by the internsespecially in terms of developing leadership skills and dispositions (Hess \& Kelly, 2005; Knapp et al., 2006). Interns were enthusiastic not so much about the experience of techniques such as the 360-degree project leader evaluation but more so about the self-development and selfawareness that such techniques induced. Again, to what extent the content of the program has given the interns the necessary expertise in instruction, as argued by Fry et al. (2006), Levine (2005), and others, remains to be seen. 
Many interns thought that they had good opportunities to apply in their buildings what they had learned in class sessions (Davis et al., 2005). They identified the length and depth of the internship experiences as contributing to these opportunities (Grogan \& Andrews, 2002). However, some mentor principals believed that the classroom projects and practical expectations could have been better aligned.

Not all interns experienced the same level of mentorship from their mentor principals. Some principals allowed the interns to directly participate in leadership tasks with parents, teachers, and students. Other interns spent more time observing the principals interacting with these stakeholders. Some interns received a clear set of expectations of what they would learn during their internship, and others were left feeling a sense of haphazardness. Some interns expressed being undersupported and that they were expected to follow more often than they were to lead (Fry et al., 2005).

Better communication between facilitator expectations and mentor expectations would address this inconsistency. Some mentor principals were more regular attendees at required meetings of the mentors than others, which surely influenced their perceptions of expectations. Finally, interns also commented on the criteria used for placement as intern in the buildings. Some felt they were there because the principal simply wanted another body for the administrative team, and did not provide the intern with a rich set of opportunities. The choice of mentor principals for the second cohort will be more carefully scrutinized as a result of these findings.

These first efforts have to some extent addressed Levine's criticisms (2005) about ineffective program delivery and outdated content. However, attention must clearly be paid to content-mentors and facilitators noted such areas of weakness. The interns believed that they were getting necessary information during the program, but we need to listen closely to their feedback after they have been in their administrative positions for a while. Also, using the instructional strategies from the New York Leaders Academy and co-constructing and co-delivering the Old City Leadership Program provide good points of departure from the traditional program that Levine decried. Yet, we have work to do if we want to co-construct a radically different preparation program.

\section{IMPLICATIONS FOR RESEARCHERS}

Researchers of preparation programs that are embedded in districtuniversity partnerships can build on the findings from our study. Conceptually, we need to understand how partnerships are coupled. We did not have a sense of the tightness or looseness that would be appropriate to deliver this program. Current research is not explicit on the factors that in- 
fluence the strength of the relationship. We found that our attention was fully consumed in the co-construction and co-delivery of the program and less on which aspects of the partnership should be tightly structured and which should be loosely structured. Further research is also necessary to understand how nondirectly involved district administrative personnel view the partnership. We have no data that indicate their senses of what the partnership was attempting to achieve.

\section{IMPLICATIONS FOR CO-CONSTRUCTORS AND CO-DELIVERERS}

We encourage many others to form district-university partnerships. Despite our inexperience in preparing first-time leaders in the way that we did, we all found it an energizing activity. We realize, however, that programs that are designed to respond to the concerns and criticisms in the literature look different from one another. Our findings suggest that a collaborative such as the one that we forged takes a long time to mature. We would be interested in learning whether this aspect is true in other, similar partnerships; we would like to know how our experiences compare. Action research is transferable to other settings inasmuch as the participants are attempting to achieve the same goals that we were in this program. A meta-analysis of partnerships would be a useful addition to the literature on this topic. The more that we engage in this work as a field, the more that we will learn.

\section{CONCLUSION}

The loosely coupled nature of the partnership meant that, outside the two district facilitators, few district personnel were knowledgeable of the program. A closer working relationship between the district central office and the university-district instructional team has emerged as a desirable objective. Such a relationship would facilitate the recruitment and selection of talented participants in subsequent cohorts; it would also assist in the placement of interns at the conclusion of the program.

We experienced a partnership that met most of our goals, as the data clearly show. However, we need to give thought to how our future relationship can be even more effective. We see this partnership as a novice one that needs to develop as we build trust. This time, we concentrated on innovative delivery of a program. Next time, we can look closely at how our different strengths can offer a synergy that is beyond the day-to-day immersion in the instruction of interns.

Are we satisfied with our ambitious program? The data indicate that we have co-constructed an exciting leadership preparation experience for this 
first group of principal candidates in the Old City Leadership Program. But still we have much to do. The themes that emerged from the data tell us that we were successful in readying and preparing about half our interns, and we learned that our partnership was too loosely coupled to enable us to get the most out of the innovations that we put into place.

Our next challenge is to keep the partnership alive long enough to study graduates of the program as they reach the principalship. Then we can weave their experiences into the preparation of new first-time leaders. In addition, we hope to support those in the principalship by building on what they have learned in their preparation. We trailblazers have learned that a 15-month preparation program can ready many talented individuals for school leadership positions, but we do not yet know how they will lead. Above all, this study gives us hope that a mature partnership between district and higher education can provide the nurturing and critical intervention needed for expert instructional leadership to develop.

\section{APPENDIX: SAMPLE INTERVIEW PROTOCOL}

\section{QUESTIONS FOR INTERNS}

1. Has this program helped you to develop your leadership skills? If so, how? If not, why not?

2. What particular aspects of the program have you found to be most useful to you in your development as an urban leader in the Old City Public Schools?

3. What particular aspects of the program have you found to be least useful to you in your development as an urban leader in the Old City Public Schools?

4. As you reflect on the methods of instruction that have been used, which have you found to be most effective? Least effective?

5. What advice or suggestions do you have for the instructional team to strengthen the program at this stage?

6. Are there any other observations or comments you would like to make?

\section{QUESTIONS FOR MENTOR PRINCIPALS}

1. As you reflect on your role as a mentor principal, has the experience helped you to improve your leadership skills? If so, how? If not, why not?

2. How did your core values influence your role as a mentor principal in the preparation of new leaders for the Old City Public Schools?

3. Which strategies/activities that you created for your interns were most effective in helping them to develop as instructional leaders? 
4. How effective was your mentorship in helping the interns' decisionmaking skills of recognizing a problem and using appropriate analysis to make sound decisions? Please provide an example.

5. How did you help your interns to recognize and/or admit their errors and learn from mistakes and setbacks?

6. What effect has this program had on your own reflective practice?

7. If you were to mentor another aspiring principal in the future, what might you do differently next time?

8. As you reflect on being a mentor principal during the 2005-2006 school year, what aspects of the program do you consider to be the most beneficial for developing new principals for the Old City Public Schools?

9. What advice or suggestions do you have for the leadership partnersthe school district and the university - to strengthen or improve the program when it is done again with another group of teachers?

10. What other observations or comments would you like to make?

\section{REFERENCES}

Barnett, B. G. (2005). Transferring learning from the classroom to the workplace: Challenges and implications for educational leadership preparation. Educational Considerations, 32(2), 6-16.

Barnett, B. G., Basom, M. R., Yerkes, D. M., \& Norris, C. J. (2000). Cohorts in educational leadership programs: Benefits, difficulties, and the potential for developing school leaders. Educational Administration Quarterly, 36(2), 255-282.

Barnett, B. G., \& Muse, I. D. (1993). Cohort groups in educational administration: Promises and challenges. Journal of School Leadership, 3, 400-415.

Barnett, D. (2004). School leadership preparation programs: Are they preparing tomorrow's leaders? Education, 125(1), 121-129.

Behar-Horenstein, L. S. (1995). Promoting effective school leadership: A changeoriented model for the preparation of principals. Peabody Journal of Education, $70,18-40$.

Blase, J., \& Blase, J. (1999). Principals' instructional leadership and teacher development: Teachers' perspectives. Educational Administration Quarterly, $35(3), 349-378$.

Bradbury, H., \& Reason, P. (2001). Conclusion: Broadening the bandwidth of validity: Issues and choice-points for improving the quality of action research. In P. Reason \& H. Bradbury (Eds.), Handbook of action research (pp. 447-456). Thousand Oaks, CA: Sage.

Brandt, D. (1990). Getting social about critical thinking: Power and constraints of apprenticeship. Quarterly Neusletter of the Laboratory of Comparative Human Cognition, 12(2), 56-63.

Bredeson, P. V. (2004). Creating spaces for the development of democratic school leaders: A case of program redesign in the United States. Journal of Educational Administration, 42(6), 708-723. 
Brewster, C., \& Klump, J. (2005). Leadership practices of successful principals. Portland, OR: Northwest Regional Educational Laboratory.

Brooks, J., \& Brooks, M. (1993). The case for constructivist classrooms. Alexandria, VA: Association for Supervision and Curriculum Development.

Brown, K. (2006). A transformative andragogy for principal preparation. UCEA Review, 45(2), 1-5.

Browne-Ferrigno, T. (2003). Becoming a principal: Role conception, initial socialization, role-identity transformation, purposeful engagement. Educational Administration Quarterly, 39(4), 468-503.

Browne-Ferrigno, T., \& Muth, R. (2003). Effects of cohorts on learners. Journal of School Leadership, 13(6), 621-643.

Browne-Ferrigno, T., \& Muth, R. (2004). Leadership mentoring in clinical practice: Role socialization, professional development, and capacity building. Educational Administration Quarterly, 40(4), 468-494.

Cambron-McCabe, N., \& Cunningham, L. (2002). National commission for the advancement of educational leadership: Opportunity for transformation. Educational Administration Quarterly, 38(2), 289-299.

Chenowith, T., Carr, C., \& Ruhl, T. (2002, August). Best practices in educational leadership preparation programs. Paper presented at the Administrator Licensure Planning Forum, University of Oregon, Eugene.

Cicchinelli, L., Dean, C., Galvin, M., Goodwin, B., \& Parsley D. (2006). Success in sight: A comprehensive approach to school improvement. Denver, CO: Midcontinent Research for Education and Learning.

Coghlan, D., \& Brannick, T. (2005). Doing action research in your own organization. London: Sage.

Cornbleth, K. (1990). Curriculum in context. New York: Falmer Press.

Cotton, K. (2003). Principals and students achievement. What the research says. Alexandria, VA: Association for Supervision and Curriculum Development.

Daresh, J. (2004). Mentoring school leaders: Professional promise or predictable problems? Educational Administration Quarterly, 40(4), 495-517.

Davis, S., Darling-Hammond, L., LaPointe, M., \& Meyerson, D. (2005). School leadership study: Developing successful principals. Stanford, CA: Stanford Educational Leadership Institute.

Diller, P. F. (2004). Duquesne University IDPEL cohorts: A laboratory for leadership. Unpublished doctoral dissertation, Duquesne University, Pittsburgh, PA.

Donaldson, J. F., \& Scribner, J. P. (2003). Instructional cohorts and learning: Ironic uses of a social system. Journal of School Leadership, 13, 644-665.

Duke, D., Butin, D., \& Sofka, A. (2003). The impact of Virginia's accountability plan on high school English departments. In D. Duke, M. Grogan, P. Tucker, \& W. Heinecke (Eds.), Educational leadership in an age of accountability (pp. 135-154). Albany, NY: SUNY Press.

Ferrandino, V. (2001). Challenges for 21st-century elementary school principals. Phi Delta Kappan, 42(6), 440-442.

Fry, B., Bottoms, G., \& O'Neill, K. (2005, April). The principal internship: How can we get it right? Atlanta, GA: Southern Regional Education. 
Fry, B., O'Neill, K., \& Bottoms, G. (2006). Schools can't wait: Accelerating the redesign of university principal preparation programs. Retrieved October 28, 2006, from http://www.wallacefoundation.org/KnowledgeCenter/KnowledgeTopics/ EducationLeadership/

Goldring, E., \& Sims, P. (2005). Modeling creative and courageous school leadership through district-university-community partnerships. Educational Policy, 19(1), 223-249.

Gonder, P. (1999). Invigorating education by reinventing staff development. In Midcontinent Regional Education Laboratory (Ed.), Noteworthy perspectives on comprehensive school reform. Aurora, CO: Authors.

Grogan, M. (1999). Equity/equality issues of gender, race and class. Educational Administration Quarterly, 35(4), 518-536.

Grogan, M., \& Andrews, R. (2002). Defining preparation and professional development for the future. Educational Administration Quarterly, 38(2), 233-256.

Grogan, M., \& Roberson, S. (2002). Developing a new generation of educational leaders by capitalizing on partnerships. International Journal of Educational Management, 16(6/7), 314-318.

Grogan, M., \& Roland, P. (2003). A study of successful teachers preparing high school students for the standards of learning tests in Virginia. In D. Duke, M. Grogan, P. Tucker, \& W. Heinecke (Eds.), Educational leadership in an age of accomintability (pp. 114-134). Albany: State University of New York Press.

Harle, A. Z. (2000). Leadership academy: One system's solution to leadership training. Delta Kappa Gamma Bulletin, 6\%(1), 56-59.

Herr, K., \& Anderson, G. L. (2005). The action research dissertation: A guide for students and faculty. Thousand Oaks, CA: Sage.

Hess, F. M., \& Kelly, A. P. (2005). An innovative look, a recalcitrant reality: The politics of principal preparation reform. Retrieved October 28,2006 , from http://www.aei.org/publications/pubID.22126/pub_detail.asp

Hill, P. T., Campbell, C., \& Harvey, J. (2000). It takes a city. Washington, DC: Brookings Institution Press.

Knapp, M., Copland, M., Plecki, M., \& Portin, B. (2006). Leading, learning and leadership support. Retrieved February 8, 2008, from http://depts.washington .edu/ctpmail/PDFs/Synthesis-Oct16.pdf

Kochan, F. (1999). A collage of voice and form: A summary of the findings. In F. Kochan, B. Jackson, \& D. Duke (Eds.), A thousand voices from the firing line (pp. 104-110). Columbia, MO: University Council for Educational Administration.

Kochan, F., Jackson, B., \& Duke, D. (Eds.). (1999). A thousand voices from the firing line, Columbia, MO: University Council for Educational Administration.

Leithwood, K., Louis, K. S., Anderson, S., \& Wahlstrom, K. (2004). How leadership influences student learning. New York: Wallace Foundation.

Levine, A. (2005). Educating school leaders. Retrieved July 13, 2006, from http:// www.wallacefoundation.org/WF/ELAN/TR/KnowledgeCategories/ DevelopingLeaders/Training/educating_school_leaders.htm 
McCabe, D. H., Ricciardi, D., \& Jamison, M. G. (2000). Listening to principals as customers: Administrators evaluate practice-based preparation. Planning and Changing, 31(3/4), 206-225.

McREL. (2005). Final report: High-needs schools-what does it take to beat the odds? Aurora, CO: Author.

Milstein, M. M. (1995). Progress and perils: Development of the field-based Ed.D. program in educational administration at the University of New Mexico. Planning \& Changing, 26, 130-47.

National Center for Children in Poverty. (2006). Fact sheets. Retrieved July 23, 2006, from www.hccp.org.

National Research Service. (2003). K-12 principals guide to No Child Left Behind. National Association of Elementary School Principals and the National Association of Secondary Principals.

Norris, C., Barnett, B., Basom, M., \& Yerkes, D. (1996). The cohort: A vehicle for building transformational leadership skills. Planning and Changing, 27(3/4), 145-164.

O'Donnell, R. J., \& White, G. P. (2005). Within the accountability era: Principals instructional leadership behaviors and students achievement. NASSP Bulletin, $89,56-71$.

Pounder, D., Reitzug, U., \& Young, M. D. (2002). Preparing school leaders for school improvement, social justice, and community. In J. Murphy (Ed.), The educational leadership challenge: Redefining leadership for the 21st century (pp. 261-288). Chicago: National Society for the Study of Education.

Schon, D. (1983). The reflective practitioner: How professionals think in action. New York: Basic Books.

Scribner, J. P., Cockrell, K. S., Cockrell, D. H., \& Valentine, J. W. (1999). Creating professional communities in schools through organizational learning: An evaluation of a school improvement process. Educational Administration Quarterly, 35(1), 130-160.

Smith, W. F., \& Andrews, R. L. (1989). Instructional leadership: How principals make a difference. Alexandria, VA: Association for Supervision and Curriculum Development.

Starratt, R. J. (2004). Ethical leadership. San Francisco: Jossey-Bass.

Tirozzi, G. (2001). The artistry of leadership: The evolving role of the secondary school principal. Phi Delta Kappan, 42(6), 434-439.

Tucker, P. D. (2003). The principalship: Renewed call for instructional leadership. In D. Duke, M. Grogan, P. Tucker, \& W. Heinecke (Eds.), Educational leadership in an age of accountability (pp. 97-113). Albany, NY: SUNY Press.

Tucker, P. D., Henig, C. B., \& Salmonowicz, M. J. (2005). Learning outcomes of an educational leadership cohort program. Educational Considerations. Retrieved November 1, 2005, from http://www.coe.ksu.edu/EdConsiderations

Waters, J. T., Marzano, R. J., \& McNulty, B. A. (2003). Balanced leadership: What 30 years of research tells us about the effect of leadership on students achievement. Aurora, CO: Mid-Continent Research for Education and Learning.

Wenger, P. (1999). Selecting and implementing research-based instruction. In Midcontinent Regional Educational Laboratory (Ed.), Notewonthy perspectives on comprehensive school reform. Aurora, CO: Author. 
Whitaker, K. S., \& Barnett, B. G. (1999). A partnership model linking K-12 school districts and leadership preparation programs. Planning and Changing, 30(3/4), 126-143.

Whitaker, K. S., King, R., \& Vogel, L. R. (2004). School district-university partnerships: Graduate students perceptions of the strengths and weaknesses of a reformed leadership development program. Plamning and Changing, 35(3/4), 209-222.

Young, M., Peterson, G., \& Short, P. (2002). The complexity of substantive reform: A call for interdependence among key stakeholders. Educational Administrative Quarterly, 38(2), 137-175.

Juanita Cleaver Simmons is an assistant professor at the University of MissouriColumbia in the Educational Leadership and Policy Analysis division. Her career in urban public school administration and classroom teaching adds practical knowledge to her research interest in leadership and the national achievement gap.

Margaret Grogan is currently professor and chair, Department of Educational Leadership and Policy Analysis, University of Missouri-Columbia. A past president of the University Council of Educational Administration, she has taught and researched educational leadership preparation and development. She also researches women in leadership, the superintendency, the moral and ethical dimensions of leadership, and leadership for social justice.

Stacey Jones Preis is a doctoral student in educational leadership and policy analysis at the University of Missouri-Columbia. Her research and professional interests include the impact of social class on educational outcomes and state-level education policy development.

Kristin Matthews recently received her doctorate in educational administration from the University of Missouri. She is currently assistant principal at Gentry Middle School, Columbia, Missouri.

Sheila Smith-Anderson is the executive director of leadership development for the St. Louis Public Schools. She began her career in Kentucky as a classroom teacher and principal. She worked with the Kentucky Department of Education as a distinguished educator working with school reform and with the Collaborative for Teaching and Learning as an educational program consultant.

Betty Porter Walls is an associate professor of practice in the Educational Leadership and Policy Analysis division at the University of Missouri-Columbia. Her teaching specializations include leadership development, organizational management, diversity, and curriculum and instruction. She is the professor and co-facilitator for the New Leaders Project in the St. Louis Public School District.

Audrey Jackson is program coordinator for the Wallace Foundation Leadership Development Grant for Aspiring Principals in the St. Louis Public School District. She also currently serves on the board of directors for the National Council of Teachers of Mathematics. 


\section{COPYRIGHT INFORMATION}

TITLE: Preparing First-Time Leaders for an Urban Public School District: An Action Research Study of a Collaborative District-University Partnership

SOURCE: J Sch Leadership 17 no5 S 2007

The magazine publisher is the copyright holder of this article and it is reproduced with permission. Further reproduction of this article in violation of the copyright is prohibited. To contact the publisher:

http://www.rowmaneducation.com/Journals/JSL/ 